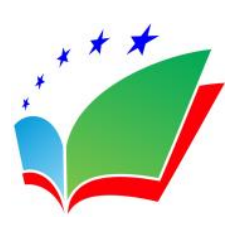

European Journal of Fitness, Nutrition and Sport Medicine Studies

ISSN: 2668 - 9758

ISSN-L: 2668 - 9758

Available on-line at: $\underline{\text { www.oapub.org/hlt }}$

DOI: $10.46827 /$ ejfnsm.v1i2.81

Volume 1 | Issue 2 | 2020

\title{
MORPHOLOGICAL-CONDITIONAL PARAMETERS OF THE FINALIST FIFA WORLD CUP 2018
}

\author{
Marko Joksimovići \\ Milan Anđelić ${ }^{2}$ \\ Kosta Goranovićs, \\ Ana Lilić, \\ Dejan Ćeremidžić, \\ Novica Gardašević \\ Niko Raičković ${ }^{1}$ \\ ${ }^{1}$ Coach Education Center, \\ Football Association of Montenegro, \\ Montenegro \\ ${ }^{2} \mathrm{PhD}$ candidate, \\ Faculty of Sport and Physical Education, \\ University of East Sarajevo, \\ Bosnia and Herzegovina \\ 3Faculty of Sports Management, \\ University of Donja Gorica, \\ Podgorica, Montenegro \\ ${ }^{4}$ Faculty of Sport and Physical Education, \\ University of Niš, Serbia \\ ${ }^{2}$ Faculty of Sport and Physical Education, \\ University of East Sarajevo, \\ Bosnia and Herzegovina \\ 5Elementary school Dobrislav Đ. Perunović, \\ Nikšić, Montenegro \\ ${ }^{1}$ Coach Education Center, \\ Football Association of Montenegro, \\ Montenegro
}

\begin{abstract}
:
The FIFA World Cup (FWC) is a football (soccer) tournament that happens every four years, gathering 31 national teams world-wide who have secured qualification and the host team. In order to gain more knowledge and information about football, it seemed necessary to analyze the periods of activity during the match. The analysis and characteristics of the effort during the match aims to enable fine modeling of activities in order to assess the specificity of playing positions, to adjust the content of training in order
\end{abstract}

i Correspondence: email nicifor007@outlook.com 
to improve the sports preparation of players and to guide and make tactical decisions. The aim of the research was to determine the differences in the morphological and fitness parameters of the finalists of the FWC 2018, as well as to obtain basic data on the character of the physical parameters of the two teams during the match, the final. Statistically significant differences were recorded in the variable distance traveled in ball possession (in poss) with statistical significance of $\mathrm{p}<.001$, while in other variables no statistical significance was recorded. These results provide information to sports scientists on performance requirements in teams with different percentages of ball possession, which could be used to individualize dual training based on tactical strategy and visualexploratory action of players during a football game.

Keywords: tactics, passing distances during the match, possession of the ball, sprint

\section{Introduction}

The FWC is a football (soccer) tournament thathappens every four years, gathering 31 national teams world-wide who have secured qualification and the host team. The tournament starts with a group stage, in which two over fourteams qualify for the subsequent knock-out stage. In the eventof a draw during the regular 90-min playing time in the knock-out stage, teams may have to dispute an extra time consistingof an additional 30-min period (two 15-min halves separated bya short break), extending the match duration up to 120 minplus additional time. Interestingly, three out of the last four FWC finals required extra time, with the match being decided inthat period in two of them. Understandably, practitioners work-ing at the elite level in football perceive the extratime as animportant period for determining success in knock-out footballmatch-play (Rago et al., 2020).

Over the last twenty years, scientific interest in football has grown significantly. In order to gain more knowledge and information about football, it seemed necessary to analyze periods of activity during the match (Bangsbo, Mohr, \& Krustrup, 2006; Burgess, Naughton, \& Norton, 2006; Di Salvo et al., 2007; Edgecomb, \& Norton, 2006; Rampinini, Impellizzeri, Castagna, Coutts, \& Wisløff, 2009). The analysis and characteristics of the effort during the match aims to enable fine modeling of activities in order to assess the specificity of playing positions, to adapt the content of training to improve sports preparation of players and guide and make tactical decisions (Krustrup et al., 2006; Mohr, Krustrup , \& Bangsbo, 2003). There are a large number of studies that have described the activity profiles of top footballers (Valter, Adam, Barry, \& Marco, 2006; Mohr et al., 2003; Rampinini et al., 2007; Rienzi, Drust, Reilly, Carter, \& Martin, 2000) . Football has been characterized as an occasional activity with short bursts of intense effort (Střlen, Chamari, Castagna, \& Wisløff, 2005). Professional footballers cover a greater total distance and more, have a higher intensity of running more intensely compared to footballers competing in lower leagues (Mohr et al., 2003; Rienz et al., 2000; Reilly, 2003). Other studies have shown that each playing position in top football is characterized by a typical 
activity profile (Di Salvo et al., 2007; Mohr et al., 2003; Rienz et al., 2000) and to the players' performance during a match is also affected by the type of competition in which players participate (Rienz et al., 2000). Footballers perform between 150 and 250 short, intense sprints during a match, and that number increases with the level of play and varies throughout the season according to the competition phase (Mohr et al., 2003). This author also showed that the position of the players has a significant impact on the number of sprints performed during the match. Mohr et al. (2003) and Mohr, Krustrup, \& Bangsbo (2005) obtained results in which it can be seen that defensive players run less than other players, while attackers and defenders have more sprints compared to midfielders and defenders. During the second half, the results indicate that the overall running distance run and high-intensity running decrease as a result of fatigue in the first half (Mohr et al., 2003). In the same study, the authors obtained results showing that measures of match performance of total distance traveled and distance traveled through high-intensity running of professional football players varied throughout the season (Mohr et al., 2003). When it comes to morphological differences in football players in relation to the position in the team in the work (Lilic, Jezdimirovic, Prvulovic, \& Joksimovic, 2019) indicate statistically significant differences between midfielders and attackers in the values of muscle mass $(\mathrm{kg})$ and body weight. (kg). Silvestre, West, Maresh, \& Kraemer (2006) conclude that midfielders have a lower percentage of body fat and higher values of lean body mass compared to attackers. Also, Lago-Peñas, Rey, Casáis, \& Gómez-López (2014) obtain similar results in which it can be seen that midfielders have slightly lower body weight percentage values compared to attackers. Midfield players have a slightly lower level of body fat percentage, but without statistically significant differences compared to other players (Lago-Peñas, Casais, Dellal, Rey, \& Domínguez, 2011). There are a large number of researches based on the analysis and characteristics of physical effort during the match in professional football. However, in the field of research, there are a small number of papers aimed at examining whether there are differences in fitness parameters between teams competing in top leagues or competitions. The aim of the research was to determine the differences in the morphological and fitness parameters of the finalists of the FWC 2018, as well as to obtain basic data on the character of the physical parameters of the two teams during the match, the final.

\section{Material and Methods}

\subsection{Participants}

For the study of morphological characteristics and fitness parameters, a sample of 27 professional football players was included, namely 14 football players of the national team of the France average age (Mean \pm Std.Dev) $28.29 \pm 3.81$, body height $184.00 \pm 7.81 \mathrm{~cm}$, body weight $76.64 \pm 5.90 \mathrm{~kg}$, BMI $22.65 \pm 1.44 \mathrm{~kg} / \mathrm{m} 2$, and 13 football players of the Croatian national team with an average age of $30.77 \pm 3.27$, body height $183.92 \pm 5.20 \mathrm{~cm}$, body weight $77.31 \pm 6.29 \mathrm{~kg}$, BMI $22.80 \pm .89 \mathrm{~kg} / \mathrm{m} 2$. The research analyzed only the 
players who played the game (starting lineup and reserve players who came in from the bench).

\subsection{Data collection}

All data used in the research were downloaded from the site (https://www.fifa.com/fifatournaments/archive/). As all data is available on the official FIFA website, the study did not require ethical approval or consent forms. In this research, the morphological and fitness parameters of the finalists of the FWC in Moscow between the national teams of France and Croatia played on July 15, 2018 were analyzed. Condition parameters that were analyzed are: distance covered during the match (Total distance), distance covered in the first half (1st half), distance covered in the second half (2nd half), distance covered in possession of the ball (In poss), number of sprints during the match (Sprint) and maximum speed during the match (Top speed). The morphological characteristics analyzed in this study are: Body Height, Body Weight and Body Mass Index.

\subsection{Statistical analysis}

Descriptive statistics were presented using the arithmetic mean (Mean) and standard deviation (Std.Dev.), While the T-test was used to determine the differences, where the statistical significance was set top $\leq 0.05$. Data analysis was performed using the statistical package for social science software (IBM SPSS Statistics for Windows, Version 20.0.).

\section{Results}

Table 1 shows the numerical quantitative indicators of the morphological status of football players. The average body height and weight of professional footballers is between 180$185 \mathrm{~cm}$ and $70-75 \mathrm{~kg}$ when all players are taken into account while BMI values range from $22.8 \pm 1.1 \mathrm{~kg} / \mathrm{m} 2$ to $23.2 \pm 1.1 \mathrm{~kg} / \mathrm{m} 2$ (Joksimovic et al. 2019). Guided by the set norms, we can conclude that the football players of both national teams meet the stated norms. No statistically significant differences in morphological characteristics were recorded between the football players of France and Croatia.

Table 1: Differences between morphological characteristics

\begin{tabular}{|c|c|c|c|c|c|}
\hline Anthropometry & National Team & $\mathbf{N}$ & Mean \pm Std.Dev. & \multicolumn{2}{|c|}{ T-test } \\
\hline & & & & $\mathbf{t}$ & p \\
\hline Body Height & $\begin{array}{l}\text { France } \\
\text { Croatia }\end{array}$ & $\begin{array}{l}14 \\
13\end{array}$ & $\begin{array}{l}184.00 \pm 7.81 \\
183.92 \pm 5.20\end{array}$ & .030 & .976 \\
\hline Body Weight & $\begin{array}{l}\text { France } \\
\text { Croatia }\end{array}$ & $\begin{array}{l}14 \\
13\end{array}$ & $\begin{array}{l}76.64 \pm 5.90 \\
77.31 \pm 6.29\end{array}$ & -.283 & .779 \\
\hline Body Mass Index & $\begin{array}{l}\text { France } \\
\text { Croatia }\end{array}$ & $\begin{array}{l}14 \\
13 \\
\end{array}$ & $\begin{array}{c}22.65 \pm 1.44 \\
22.80 \pm .89\end{array}$ & -.322 & .750 \\
\hline
\end{tabular}

Table 2 shows the descriptive statistics (Mean \pm Std.Dev.) as well as the difference between the fitness parameters between the two national teams. Statistically significant differences 
were recorded in the variable distance covered with ball in possession (In poss) with a statistical significance of $p<.001$. Figure 1 shows the average values of fitness parameters for both teams.

Table 2: Differences in conditioning parameters

\begin{tabular}{|c|c|c|c|c|c|}
\hline \multirow[t]{2}{*}{ Variables } & \multirow[t]{2}{*}{ National Team } & \multirow[t]{2}{*}{$\mathbf{N}$} & \multirow[t]{2}{*}{ Mean \pm Std.Dev. } & \multicolumn{2}{|c|}{ T-test } \\
\hline & & & & $t$ & $\mathrm{p}$ \\
\hline Total distance & $\begin{array}{l}\text { France } \\
\text { Croatia }\end{array}$ & $\begin{array}{l}14 \\
13\end{array}$ & $\begin{array}{l}7.088 \pm 2.79 \\
7.712 \pm 3.10\end{array}$ & -.549 & .588 \\
\hline $1^{\text {st }}$ half & $\begin{array}{l}\text { France } \\
\text { Croatia }\end{array}$ & $\begin{array}{l}11 \\
11\end{array}$ & $\begin{array}{l}4.178 \pm .78 \\
4.316 \pm .93\end{array}$ & -.374 & .712 \\
\hline $2^{\text {nd }}$ half & $\begin{array}{l}\text { France } \\
\text { Croatia }\end{array}$ & $\begin{array}{l}14 \\
13\end{array}$ & $\begin{array}{l}3.824 \pm 1.43 \\
4.059 \pm 1.44\end{array}$ & -.423 & .676 \\
\hline In poss & $\begin{array}{l}\text { France } \\
\text { Croatia }\end{array}$ & $\begin{array}{l}14 \\
13 \\
\end{array}$ & $\begin{array}{c}1.900 \pm .79 \\
3.505 \pm 1.41\end{array}$ & -3.670 & .001 \\
\hline Top Speed & $\begin{array}{l}\text { France } \\
\text { Croatia }\end{array}$ & $\begin{array}{l}14 \\
13\end{array}$ & $\begin{array}{l}27.99 \pm 3.62 \\
27.32 \pm 4.27\end{array}$ & .434 & .668 \\
\hline Sprint & $\begin{array}{l}\text { France } \\
\text { Croatia }\end{array}$ & $\begin{array}{l}14 \\
13\end{array}$ & $\begin{array}{l}24.46 \pm 11.60 \\
29.08 \pm 13.55\end{array}$ & -.918 & .368 \\
\hline
\end{tabular}

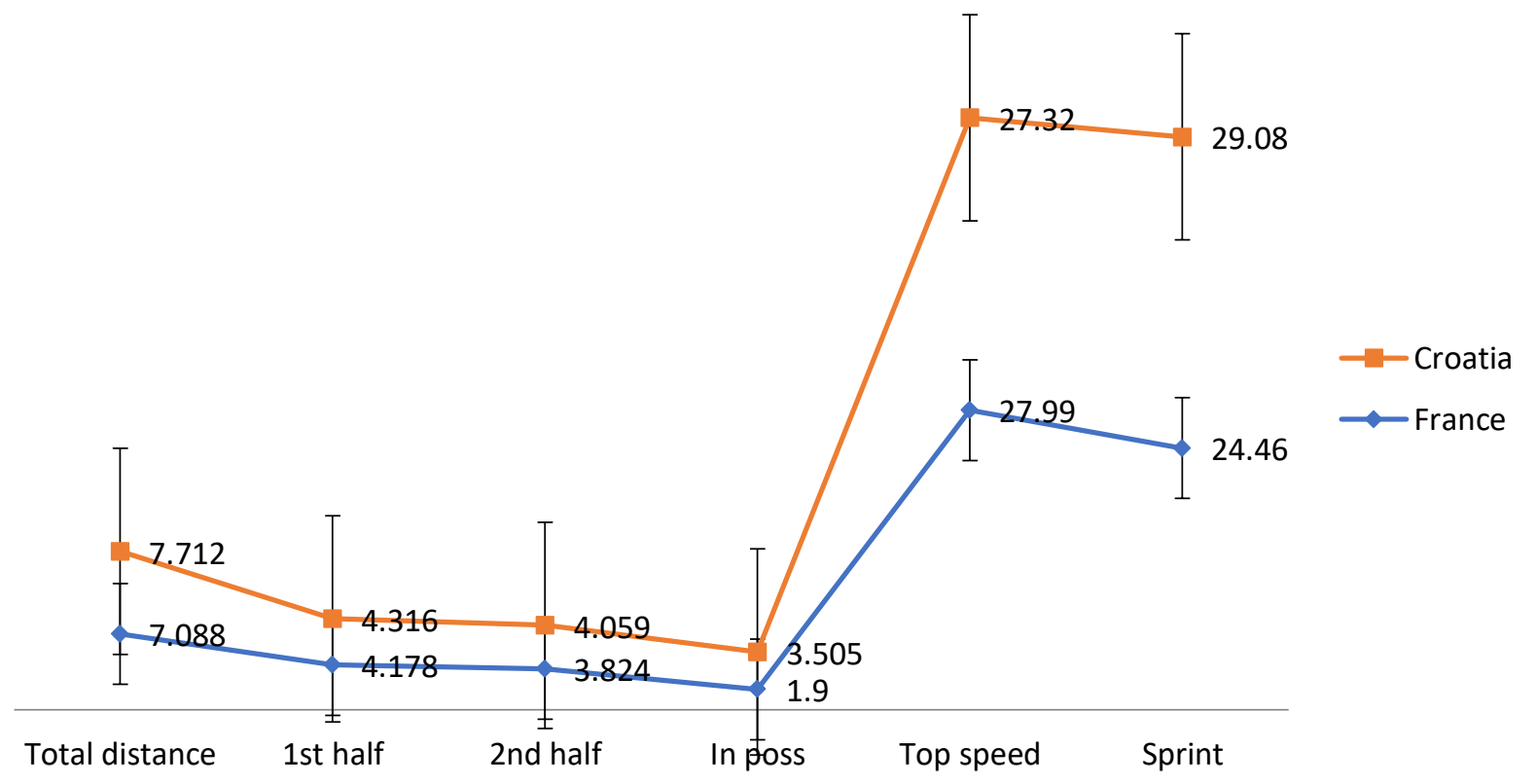

Figure 1: Average values of conditioning parameters

\section{Discussion}

Morphological characteristics of football players, based on the obtained results, there are no statistically significant differences between the two national teams in professional 
football. BMI values range from $22.8 \pm 1.1 \mathrm{~kg} / \mathrm{m} 2$ to $23.2 \pm 1.1 \mathrm{~kg} / \mathrm{m} 2$ which agrees with the results in the study (Joksimovic et al. 2019). Lago-Peñas et al. (2011) conclude that there is no statistically significant difference in body composition in football players. Nikolaidis, \& Karydis, (2011) found that players under the age of 21 have average BMI values (Mean $23.77 \pm 1.57$ ). A study conducted on professional footballers competing in the Argentine league obtained results in which BMI values (Mean $24.5 \pm 1.4$ ) (Wittich, et al., 1998). The aim of the research was to determine the differences in the morphological and fitness parameters of the finalists of the FWC 2018, as well as to obtain basic data on the character of the physical parameters of the two teams during the match, the final. The total distance covered, which the players cover in the first and second half with and without the ball, in our research is France $(7.088 \pm 2.79 \mathrm{~m})$ and Croatia $(7.712 \pm 3.10 \mathrm{~m})$ without statistically significant differences $(\mathrm{p}=.588)$. Walter et al. (2006) in a work in which 300 professional footballers competing in European leagues ran an average of $(11,393 \mathrm{~m})$. The research that was done on 18 top football players, the total distance covered during the match is $(10,864 \mathrm{~m})$ (Rampinini et al., 2007). Slightly greater distance than the players of the two teams in the FWC final have Premier League players, who run in total $(10,722 \pm 978 \mathrm{~m})$, Championship players in the match run $(11,429 \pm 816 \mathrm{~m})$ and League 1 players in run $(11,607 \pm 737 \mathrm{~m})$ Bradleyet al., 2013). Also, the players of the Champions League $(11,102 \pm 916 \mathrm{~m})$ and Premier League $(10,746 \pm 964 \mathrm{~m})$, in various forms of movement, have a higher percentage than the players of France and Croatia (Di Salvo, Pigozzi, Gonzalez-Haro, Laughlin, \& De Vitt, 2013). Only in the variable of predicting the distance in possession of the ball (In poss) there is a statistically significant difference between the two teams in favor of Croatian footballers.

The most popular technical indicator in football is ball possession due to its strong association with success, but this relationship is extremely complex in the efficiency of passing and the type of offensive strategies that are also important factors associated with success (Bradley et al., 2013). Clemente et al., (2015) indicate that winning teams have a higher percentage of ball possession than teams that have lost, thus showing that success in football is associated with a high percentage of ball possession. However, our research has shown the opposite results. The Croatian team had a higher ball possession of $61 \%$ compared to the French team of $39 \%$ and lost the final game with the result 4: 2 . Justification for such results can be found in the fact that the Croatian team does not have sufficiently developed visual research activity that is important in the analysis of performance actions with the ball, actions in which they move the body, head and eyes to visually observe the game around them (McGuckin et al., 2018). Playing against a better team justifies the fact that our results show that teams of lower quality have to cover longer distances with high intensity in order to achieve greater possession of the ball. Ball possession is also affected by the venue of the match, the resistance of the opponent, cooperation between and within the lines of the opposing team as well as different styles of play (Lago, \& Martin, 2007). The players of the Croatian national team ran more than the players of France. When it comes to the differences between the two teams in the total distance covered in the first and second half, there are no statistically significant 
differences. From the mean values, we can see that in the first half (France $=4,178 \pm .78 \mathrm{~m}$; Croatia $=4,316 \pm .93 \mathrm{~m}$ ) the players move more than in the second half (France $=3,824 \pm$ $1.43 \mathrm{~m}$; Croatia $=4,059 \pm 1.44 \mathrm{~m}$ ). Other authors agree with these results because their results show that players move more in the first half than in the second half (Walter et al., 2006). Statistically significant differences between the two halves in the total distance traveled less than $\mathrm{p}<0.05$ were found by Rivilla-García et al. (2019). and less than $p<0.0001$ Borghi et al. (2020). Sprinting is one of the most important activities in football, even though it represents only $1-12 \%$ of the total distance covered in the match. Footballers are required to repeatedly make the maximum or nearest maximum sprint of short duration (1-7 s) with short recovery periods. Therefore, the ability to repeat multiple sprints at high speed is important for the physical performance of a football player. Thus, muscle strength is an important prerequisite for sprinting because it requires players to perform activities such as stepping, turning, and jumping (Rampinini et al., 2007). Variables such as the number of sprints during the match (Sprint) and the maximum speed during the match (Top speed) do not show significant differences. Slightly different results are obtained by Bradley et al. (2013) showing a statistically significant difference in favor of League 1 compared to Premier League and Championship in sprints during the match $(p<0.01)$ and between Championship League and Premier League (Di Salvo et al., 2013).

\section{Conclusion}

The data obtained by this research show that the possession of the ball does not affect the overall profile of the team's activities, but affects the composition of high-intensity efforts and some technical elements of performance. These results provide information to sports scientists on performance requirements in teams with different percentages of ball possession, which could be used to individualize dual training based on tactical strategy and visual-exploratory action of players during a football game. Also, these results can be useful to coaches when devising tactics to improve the chances of winning.

\section{Conflicts of Interest}

The authors declare no conflict of interest.

\section{References}

Bangsbo, J., Mohr, M., \& Krustrup, P. (2006). Physical and metabolic demands of training and match-play in the elite football player. Journal of Sports Sciences. 24(07): 665-674. DOI: $10.1080 / 02640410500482529$.

Borghi, S., Colombo, D., La Torre, A., Banfi, G., Bonato, M., \& Vitale, J. A. (2020). Differences in GPS variables according to playing formations and playing positions in U19 male soccer players. Research in Sports Medicine. 1-15. https://doi.org/10.1080/15438627.2020.1815201. 
Bradley, P. S., Carling, C., Diaz, A. G., Hood, P., Barnes, C., Ade, J., Boddy, M., Krustrup, P., \& Mohr, M. (2013). Match performance and physical capacity of players in the top three competitive standards of English professional soccer. Human Movement Science. 32(4): 808-821. https://doi.org/10.1016/j.humov.2013.06.002.

Bradley, S. P., Lago-Peñas, C., Rey, E., \& Gomez-Diaz, A. (2013). The effect of high and low percentage ball possession on physical and technical profiles in English FA Premier League soccer matches. Journal of Sports Sciences. 31(12): 1261-1270, DOI: 10.1080/02640414.2013.786185.

Burgess, D. J., Naughton, G., \& Norton, K. I. (2006). Profile of movement demands of national football players in Australia. Journal of Science and Medicine in Sport. 9(4): 334-341. https://doi.org/10.1016/j.jsams.2006.01.005.

Clemente, F. M., Martins, F. M. L., Kalamaras, D., Wong, P. D., \& Mendes, R. S. (2015). General network analysis of national soccer teams in FIFA World Cup 2014. International Journal of Performance Analysis in Sport. 15(1): 80-96. https://doi.org/10.1080/24748668.2015.11868778.

Di Salvo, V., Baron, R., González-Haro, C., Gormasz, C., Pigozzi, F., \& Bachl, N. (2010.) Sprinting analysis of elite soccer players during European Champions League and UEFA Cup matches. Journal of Sports Sciences. 28(14): 1489-1494. DOI: $\underline{10.1080 / 02640414.2010 .521166 .}$

Di Salvo, V., Baron, R., Tschan, H., Montero, F. C., Bachl, N., \& Pigozzi, F. (2007). Performance characteristics according to playing position in elite soccer. International Journal of Sports Medicine. 28(03): 222-227.

Di Salvo, V., Pigozzi, F., González-Haro, C., Laughlin, M. S., \& De Witt, J. K. (2013). Match performance comparison in top English soccer leagues. International Journal of Sports Medicine. 34(06). 526-532. DOI http://dx.doi.org/10.1055/s-0032-1327660.

Edgecomb, S. J., \& Norton, K. I. (2006). Comparison of global positioning and computerbased tracking systems for measuring player movement distance during Australian football. Journal of Science and Medicine in Sport.9(1-2): 25-32. https://doi.org/10.1016/j.jsams.2006.01.003.

Joksimović, M., Skrypchenko, I., Yarymbash, K., Fulurija, D., Nasrolahi, S., \& Pantović, M. (2019). Anthropometric characteristics of professional football players in relation to the playing position and their significance for success in the game. Pedagogics, psychology, medical-biological problems of physical training and sports. 23(5):54-58. https://doi.org/10.15561/18189172.2019.0401.

Krustrup, P., Mohr, M., Steensberg, A., Bencke, J., Kjær, M., \& Bangsbo, J. (2006). Muscle and blood metabolites during a soccer game: implications for sprint performance. Medicine and Science in Sports and Exercise.38(6): 1165-1174. DOI: $10.1249 / 01 . \mathrm{mss} .0000222845 .89262 . \mathrm{cd}$

Lago, C., \& Martin, R. (2007). Determinants of possession of the ball in soccer. Journal of Sports Sciences. 25: 969-974

Lago-Peñas, C., Casais, L., Dellal, A., Rey, E., \& Domínguez, E. (2011). Anthropometric and physiological characteristics of young soccer players according to their playing 
positions: relevance for competition success. The Journal of Strength $\mathcal{E}$ Conditioning Research. 25(12): 3358-3367.

Lago-Peñas, C., Rey, E., Casáis, L., \& Gómez-López, M. (2014). Relationship between performance characteristics and the selection process in youth soccer players. Journal of Human Kinetics. 40(1). 189-199. DOI: 10.2478/hukin-2014-0021

Lilic, A., Jezdimirovic, M., Prvulovic, N., \& Joksimovic, M. (2019). The relationship between muscular fitness and body composition in football. In N. Stojiljkovic (Ed.), Proceedings of the XXII Scientific Conference "FIS COMMUNICATIONS 2019" in physical education, sport and recreation (pp. 107-113). October, 17 - 19, 2019, Nis, RS: Faculty of sport and physical education, University of Niš.

McGuckian, T. B., Cole, M. H., Jordet, G., Chalkley, D., \& Pepping, G. J. (2018). Don't Turn Blind! The Relationship Between Exploration Before Ball Possession and On-Ball Performance in Association Football. Front. Psychol. 9:2520. doi: 10.3389/fpsyg.2018.02520

Mohr, M., Krustrup, P., \& Bangsbo, J. (2003). Match performance of high-standard soccer players with special reference to development of fatigue. Journal of Sports Sciences. 21(7): 519-528. DOI: 10.1080/0264041031000071182

Mohr, M., Krustrup, P., \& Bangsbo, J. (2005). Fatigue in soccer: a brief review. Journal of sports sciences. 23(6): 593-599. https://doi.org/10.1080/02640410400021286

Nikolaidis, P. T., \& Karydis, N. V. (2011). Physique and body composition in soccer players across adolescence. Asian Journal of Sports Medicine. 2(2): 75-83. doi: 10.5812 /asjsm.34782

Rago, V., Abreu, R., Vasconcellos, F., Teixeira, H. V., Rebelo, A., Figueiredo, P., \& Brito, J. (2020). Physical and technical demands of the extra time: a multiple FIFA World Cups' analysis, Science and Medicine in Football, 4(3): 171-177. DOI: $\underline{10.1080 / 24733938.2020 .1752930}$

Rampinini, E., Bishop, D., Marcora, S. M., Bravo, D. F., Sassi, R., \& Impellizzeri, F. M. (2007). Validity of simple field tests as indicators of match-related physical performance in top-level professional soccer players. International Journal of Sports Medicine. 28(03): 228-235. DOI 10.1055/s-2006-924340 •

Rampinini, E., Bishop, D., Marcora, S.M., Sassi, R., \& Impellizzeri, F. M. (2007). Validity of Sample Field test of Indicators of Match-Related Physical Performance in TopLevel Professional Soccer Players. Int. J. Sports Med. 28: 228-235

Rampinini, E., Impellizzeri, F. M., Castagna, C., Coutts, A. J., \& Wisløff, U. (2009). Technical performance during soccer matches of the Italian Serie A league: Effect of fatigue and competitive level. Journal of Science and Medicine in Sport: 12(1): 227233. doi:10.1016/j.jsams.2007.10.002

Reilly T. (2003). Motion analysis and physiological demands. In: Reilly T, Williams AM (eds). Science and Soccer. London: Routledge, 59-72.

Rienzi, E., Drust, B., Reilly, T., Carter, J. E. X. L., \& Martin, A. (2000). Investigation of anthropometric and work-rate profiles of elite South American international soccer players. Journal of Sports Medicine and Physical Fitness: 40(2): 162-169. 
Rivilla-García, J., Calvo, L. C., Jiménez-Rubio, S., Paredes-Hernández, V., Muñoz, A., Van den Tillaar, R., \& Navandar, A. (2019). Characteristics of very high intensity runs of soccer players in relation to their playing position and playing half in the 201314 Spanish La Liga season. Journal of Human Kinetics.66(1): 213-222. https://doi.org/10.2478/hukin-2018-0058

Silvestre, R., West, C., Maresh, C. M., \& Kraemer, W. J. (2006). Body Composition and Physical Performance in Men's Soccer: A study of A National Collegiate Athletic Association Division Iteam. The Journal of Strength $\mathcal{E}$ Conditioning Research. 20(1): 177-183.

Střlen, T., Chamari, K., Castagna, C., \& Wislřff, U. (2005). Physiology of soccer: an update. Sports Med. 35: 501-536. https://doi.org/10.2165/00007256-200535060-00004

Valter, D. S., Adam, C., Barry, M., \& Marco, C. (2006). Validation of Prozone ${ }^{\circledR}$ : A new video-based performance analysis system. International Journal of Performance Analysis in Sport. 6(1): 108-119. https://doi.org/10.1080/24748668.2006.11868359

Wittich, A., Mautalen, C. A., Oliveri, M. B., Bagur, A., Somoza, F., \& Rotemberg, E. (1998). Professional football (soccer) players have a markedly greater skeletal mineral content, density and size than age-and BMI-matched controls. Calcified Tissue International. 63(2): 112-117. https://doi.org/10.1007/s002239900499. 
Marko Joksimović, Milan Anđelić, Kosta Goranović,

Creative Commons licensing terms

Author(s) will retain the copyright of their published articles agreeing that a Creative Commons Attribution 4.0 International License (CC BY 4.0) terms will be applied to their work. Under the terms of this license, no permission is required from the author(s) or publisher for members of the community to copy, distribute, transmit or adapt the article content, providing a proper, prominent and unambiguous attribution to the authors in a manner that makes clear that the materials are being reused under permission of a Creative Commons License. Views, opinions and conclusions expressed in this research article are views, opinions and conclusions of the author(s). Open Access Publishing Group and European Journal of Fitness, Nutrition and Sport Medicine Studies shall not be responsible or answerable for any loss, damage or liability caused in relation to/arising out of conflicts of interest, copyright violations and inappropriate or inaccurate use of any kind content related or integrated into the research work. All the published works are meeting the Open Access Publishing requirements and can be freely accessed, shared, modified, distributed and used in educational, commercial and non-commercial purposes under a Creative Commons Attribution 4.0 International License (CC BY 4.0). 